\title{
Private liability and critical infrastructure
}

Citation for published version (APA):

Faure, M. G. (2015). Private liability and critical infrastructure. European Journal of Risk Regulation, 6(2), 229-243. https://doi.org/10.1017/S1867299X00004530

Document status and date:

Published: 01/06/2015

DOI:

10.1017/S1867299X00004530

Document Version:

Publisher's PDF, also known as Version of record

Document license:

Taverne

Please check the document version of this publication:

- A submitted manuscript is the version of the article upon submission and before peer-review. There can be important differences between the submitted version and the official published version of record.

People interested in the research are advised to contact the author for the final version of the publication, or visit the DOI to the publisher's website.

- The final author version and the galley proof are versions of the publication after peer review.

- The final published version features the final layout of the paper including the volume, issue and page numbers.

Link to publication

\footnotetext{
General rights rights.

- You may freely distribute the URL identifying the publication in the public portal. please follow below link for the End User Agreement:

www.umlib.nl/taverne-license

Take down policy

If you believe that this document breaches copyright please contact us at:

repository@maastrichtuniversity.nl

providing details and we will investigate your claim.
}

Copyright and moral rights for the publications made accessible in the public portal are retained by the authors and/or other copyright owners and it is a condition of accessing publications that users recognise and abide by the legal requirements associated with these

- Users may download and print one copy of any publication from the public portal for the purpose of private study or research.

- You may not further distribute the material or use it for any profit-making activity or commercial gain

If the publication is distributed under the terms of Article $25 \mathrm{fa}$ of the Dutch Copyright Act, indicated by the "Taverne" license above, 


\title{
Private Liability and Critical Infrastructure
}

\begin{abstract}
Michael Faure*
Private liability can potentially play a crucial role in protecting critical infrastructure. Traditional liability rules will especially play their deterrent and therefore preventive effect in the case of so-called man-made "technological" disasters. By using a strict liability role and by providing solvency guarantees potential tort-feasors can be provided with incentives to take optimal preventive measures. However, the case of nuclear accidents, addressed in more detail, makes clear that in practice those efficient liability rules that would be needed to generate this preventive effect are often not implemented at the legislative level. The legislator rather imposes financial limits on liability and provides for public funding, thus effectively granting a subsidy to operators. Those type of inefficient rules laid down in international conventions are obviously often the result of interest group politics.
\end{abstract}

As far as natural disasters are concerned liability rules can play less of a role given the fact that those are considered an "act of God". One could then only consider public authority liability. However, this is not often accepted in practice and there may also be theoretical reasons to be careful with the imposition of public authority liability. Public authorities are multitask agents which need a substantial amount of discretion. That explains that many legal systems award (partial) immunity from liability to public authorities. This leads generally to the conclusion that although liability rules can play a role in the protection of critical infrastructure those rules may have important limits as well. As a result the primary instrument to protect critical infrastructure will in practice often be safety regulation rather than liability rules.

\section{Introduction}

There are many ways in which critical infrastructure (abbreviated as CI) in a society can be disrupted. Obviously the $\mathrm{CI}$ one thinks about can be quite different, varying e.g. from telecommunications, computer networks or simply buildings and roads. Moreover, the ways in which this disruption can take place can also be quite different. In some cases it may take relatively little effort to cause large damage, e.g. with cyber-crime leading to a disruption of computer networks; in other cases there may be quite advanced technologies that lead to serious damage (like e.g. with a technological disaster resulting for example from the explosion of a petro-chemical factory).

\footnotetext{
Professor in law and Academic Director of the Maastricht European Institute for Transnational Legal Research, Maastricht University.
}

Moreover, in addition to these examples which all point at the influence of mankind (often referred to as so-called man-made disasters) the perils of nature could also cause an endangerment of CI. Natural hazards such as volcanic eruptions, flooding or hurricanes have already caused serious disruptions to CI in the past and have, moreover, been predicted to increase in the future, inter alia as a result of climate change.

The nature of the damage resulting from these disruptions can obviously be quite different as well. The accident merely results in economic losses, such as in the case of disruptions of computer networks or telecommunications (although the latter could potentially lead to more than economic losses as well). In other cases the disruption of CI could equally cause personal injury or property damage.

Notwithstanding the hence inherently broad nature of the topic, in order to provide some focus, I 
will for the purpose of this contribution assume a disruption of CI with potentially large losses. The example one could think of is a nuclear accident which would take place in the vicinity of a large city.

My task is to look at the role of private liability in the protection of CI. The way I will approach this is by looking at two traditional functions of private liability, being prevention (through deterrence) and compensation. Obviously both goals could easily be reached through other instruments as well. For example regulation could equally aim at prevention and other instruments (like insurance or the government provided compensation) could serve a role in providing compensation. However, I have been assigned the task to focus mainly on the role of private liability and will therefore limit myself to analyse the potential, but also the limits of private liability in providing prevention and compensation in case of an endangerment of $\mathrm{CI}$.

Although I provided the example of a nuclear accident, as I already mentioned, CI cannot only be endangered through man-made (technological) disasters (such as a nuclear accident) but also through natural disasters (like e.g. flooding). Although it may, at first blush, seem strange to discuss natural disasters as well when discussing the role of private liability, I will argue that there may be a role for private liability in the context of natural disasters as well. One reason is that in some cases the damage resulting from the natural disaster is particularly large because of a failure of the government to take particular preventive measures. This hence necessitates to not only focus on private liability, but on public authority liability as well. ${ }^{1}$

The remainder of this contribution will be structured as follows: I start with the easy case by analysing efficient liability rules for technological disasters leading to a disruption of CI (2). In that section the conditions under which liability rules can provide this effective protection, but also the limits, will be highlighted. Next, I analyse the scope of private liability for natural disasters, which effectively amounts to the question of public authority liability. It will be argued that both theoretically as well as in practice the scope for such a public authority liability is limited (3). The next section (4) engages in a reality check by discussing briefly the case of nuclear accidents. A discussion of the international conventions in this domain will show that to a large extent the conditions for efficient liability rules (as sketched in section 2) are not followed. The reason why private liability hence fails (at least in this particular case) to award an adequate protection of $\mathrm{CI}$ is that those conventions are largely the result of lobbying by interest groups, in this particular case the nuclear energy sector. Section 5 concludes with a few policy recommendations discussing the possibilities and challenges of applying private liability in the protection of CI, but also showing why in many cases in practice this protection may fail.

\section{Efficient Liability Rules}

As a starting point I will first review the basic theory concerning the role that liability rules could play in protecting CI. Doing so I will use the economic approach to accident law as this approach has the major advantage of having paid a lot of attention to the specific goals of liability rules in preventing particular risks and hazards. Indeed, differently than some legal approaches, economists tend to stress the fact that an exposure to liability ex post may have a desirable $e x$ ante effect of providing efficient incentives for investments in optimal preventive technology. A (side) effect of a liability rule is that it could equally lead to compensation of victims as well. ${ }^{2}$ However, victim compensation is not considered as a primary goal of liability rules in the economic approach. Rather, the exposure to liability of the risk taken is considered to have the advantage of providing incentives for prevention.

Using this economic approach to liability rules I will first sketch that this function of liability rules can in fact only be fulfilled in case of technological disasters and less so in case of natural disasters (2.1). Next, I will point to the fact that most of the criteria advanced in the literature point to favouring a strict liability rather than a negligence regime (2.2). However, the literature equally makes clear that one should not have too high expectations on liability rules and that for that reason other instruments (more particularly safety regulation and standards is-

1 See on public authority liability for damage to $\mathrm{Cl}$ also the article by Anne Van Aaken and Isabelle Wildhaber ("State Liability and Critical Infrastructure", also included in this issue).

2 See Michael Faure, "Financial Compensation for Victims of Catastrophes: a law \& economics perspective", Law \& Policy, 2007, vol. 29(3), p. 342-344. 
sued by the government) may be more effective in protecting CI (2.3).

\section{Technological versus Natural Disasters}

As was already mentioned in the introduction, CI can be endangered by a variety of different types of disasters. Many countries are victims of various types of catastrophes. A distinction is usually made between technological disasters on the one hand, which are also referred to as man-made disasters and natural catastrophes on the other hand. Examples of technological disasters are oil spills, nuclear accidents, but also explosions in particular plants or a fire in a public building. Natural catastrophes include heavy rainfall, flooding, earthquakes, volcano eruptions, tsunamis and many others. Data show that whereas the insured losses resulting from manmade disasters seem to remain constant in the period 1970-2007 there is a substantial increase in the insured losses due to natural catastrophes. ${ }^{3}$ There is a third type of catastrophe which is usually put separately, being catastrophes caused by terrorism. They are usually treated separately because on the one hand they are obviously man-made, but on the other hand they have in common with natural catastrophes that the injurer (the terrorist) can usually not be found or is insolvent, as a result of which liability rules cannot apply (which may be different in the case of other man-made disasters like fires or explosions). Moreover, in some cases it may be difficult to adequately distinguish between man-made disasters and natural catastrophes. For example heavy rainfall could in some cases lead to flooding because infrastructural works have changed rivers as a result of which the natural carrying capacity of waters has decreased and governments in some cases even have promoted building in flood prone areas. In those cases man-made activity can in fact encourage devastating consequences of the natural catastrophe.

3 See Howard Kunreuther, "Catastrophe Insurance: Challenges for the US and Asia", in Charles Scawthorn and Kiyoshi Kobayashi (eds), Asian Catastrophe Insurance (London: Risk Books, 2008), pp. 3 et sqq., at p. 5.

4 See Guido Calabresi, "Some Thoughts on Risk Distribution and the Law of Torts", Yale Law Journal (1961), pp. 499 et sqq. and see Guido Calabresi, The Costs of Accidents: A Legal and Economic Analysis (New Haven: Yale University Press, 1970).
For the question of the effectiveness of liability rules in providing incentives for preventing damage to $\mathrm{CI}$ this distinction is quite relevant. Liability rules can in fact only have the full deterrent effect (and even in that case there are serious limitations, see below) in cases of technological disasters, where a liable tortfeasor can be identified and the damage can be directly attributable to causes that are man-made. Natural disasters are often considered "acts of God". As a result no liable tortfeasor can be found, e.g. in the case of an earthquake or a volcanic eruption. Moreover, the case of terrorism to a large extent resembles more the case of natural disasters than the case of man-made disasters. Terrorist attacks are in technical sense of course man-made, but terrorists can hardly be deterred by the use of liability rules.

Hence, in the remainder I will specifically focus on the case of technological disasters and examine how liability rules could provide effective incentives in order to protect CI.

\section{Strict Liability versus Negligence}

A first question that arises is how liability rules should be shaped if liability rules should provide effective incentives for prevention. One important element in this respect is the choice of an efficient liability rule, but there are other elements which are equally important in the design of liability rules, which can affect their effectiveness. Let us address those briefly in turn.

As a starting point it can be reminded that a strong advantage of the use of liability rules is that liability rules cannot only compensate but also provide incentives for prevention since they have a deterrent effect. This was a point already made by Guido Calabresi in $1961 .{ }^{4}$ The deterrent effect of liability rules will force a potential tortfeasor to follow efficient care. The advantage of a liability rule is that a direct allocation of the social costs of accidents takes place to the source of the risk. To put this slightly more simple: the enterprise causing the particular risk will, via liability rules, also be confronted with the costs of his activity, which will precisely give incentives for prevention. Moreover, the tortfeasor, the one who creates the risks, pays the compensation as a result of which a perfect diversification of risk can take place. Some have been critical of the assumption that tort law would have any deterrent effect and would 
hence influence the behaviour of individuals. ${ }^{5} \mathrm{How}$ ever, most of these doubts only relate to the behaviour of individuals, but not to enterprises. Since the behaviour of enterprises may be more the result of a conscious cost-benefit calculus than in the case of individuals, an exposure to liability may certainly have a deterrent effect in that case. There is, moreover, also increasing empirical evidence of the deterrent effect of liability rules. ${ }^{6}$

Addressing the basic question of the choice between strict liability and negligence, economic literature has advanced that there are strong arguments in favour of a strict liability rule for ultra-hazardous activities like the operation of a petrochemical plant. The advantage of a strict liability rule is that all social costs of the accident are shifted to the tortfeasor as a result of which he will make an optimal weighing of costs and benefits and take optimal preventive measures. ${ }^{7}$ To the extent that a strict liability rule is introduced, tort law can indeed be considered as an adequate reaction to catastrophic personal injuries. $^{8}$

A problem that, however, arises is that even strict liability may only be efficient if the insolvency problem can be cured. Insolvency should be seen here as a situation where the amount of the damage is higher than the tortfeasor's wealth. In case of catastrophes this is very likely to happen. The literature has even indicated that strict liability may more easily lead to under-deterrence than negligence if an insolvency problem remains. ${ }^{9}$ When strict liability is introduced, it should hence be accompanied with some guarantee against insolvency. This is, moreover, a more general point made in economic literature: liability rules only work efficiently (in terms of both deterrence and compensation) if solvency of the tortfeasor can be guaranteed. Otherwise a so-called "judgment proof" problem will arise in which case liability rules generally may fail to lead to a deterrent effect. ${ }^{10}$ There is therefore a strong economic argument in favour of a duty to purchase financial coverage (like e.g. compulsory liability insurance) for disasters for the simple reason that the magnitude of the damage caused as a result of a disaster can greatly outweigh the assets of the individual tortfeasor. ${ }^{11}$

In sum: although strict liability can in principle be efficient for technological disasters, given a potential insolvency problem, it should be accompanied with solvency guarantees since otherwise strict lia- bility could lead to under-deterrence. Precisely for that reason there should equally be no limit on the liability of the potential tortfeasor. A so-called financial cap, which limits the liability of the tortfeasor to a particular amount, will have the same effect as insolvency, i.e. leading to under-deterrence and thus negatively affecting incentives for prevention.

Another point that remains important in the design of efficient liability rules is that liability should be attributed in such a way that all parties that contributed to the risk should be held liable to the extent that their action did indeed affect the accident risk. When several tortfeasors (the case of so-called multiple tortfeasors) have acted together a joint and several liability rule may provide incentives to the joint tortfeasors for mutual monitoring. In any case, liability of other actors who equally contributed to the loss should not be excluded, for example by exclusively channelling the liability to one selected tortfeasor, e.g. the licensee of a particular plant, thus excluding the liability of others. The latter would have the main disadvantage that the incentives of others who could equally have contributed to the loss would be negatively affected.

\section{Limits of Liability Rules}

Although, as indicated, in theory a strict liability rule could provide incentives for the protection of $\mathrm{CI}$, if

5 See for a critical perspective on tort law inter alia Richard L. Abel, "A Critique of Torts", 37 UCLA Law Review (1990), pp. 785 et sqq. and Gregory C. Keating, "Reasonableness and Rationality in Negligence Theory", 48 Stan. L. Rev. (1996), pp. 311 et sqq.

6 See Ben C.J. van Velthoven, "Empirics of Tort", in Michael Faure (ed.), Tort Law and Economics, $2^{\text {nd }}$ ed. (Cheltenham: Edward Elgar, 2009), pp. 453 et sqq.

7 See Steven Shavell, "Strict Liability versus Negligence", Journal of Legal Studies (1980), pp. 1 et sqq.

8 William M. Landes and Richard A. Posner, "Tort Law as a Regulatory Regime for Catastrophic Personal Injuries", 13 Journal of Legal Studies (1984), pp. 417 et sqq.

9 Landes and Posner, "Tort Law as a Regulatory Regime", supra note 8; Michael Faure and David Grimeaud, "Financial Assurance Issues of Environmental Liability", in Michael Faure (ed.), Deterrence, Insurability and Compensation in Environmental Liability. Future Developments in the European Union (New York: Springer, 2003), pp. 7 et sqq., at pp. 35-36.

10 Steven Shavell, "The Judgment Proof Problem", 6 International Review of Law and Economics (1986), pp. 43 et sqq.

11 So also Howard C. Kunreuther and Paul K. Freeman, "Insurability, Environmental Risks and the Law", in Anthony Heyes (ed.), The Law and Economics of the Environment (Cheltenham: Edward Elgar, 2001), pp. 302 et sqq. 
that solvency guarantees are in place and liability is effectively attributed to all those who contributed to the risk, in practice there can be many reasons why liability rules generally may not provide their deterrent effect. These limits of liability rules have been identified in the well-known work of Shavell on the choice between liability rules and safety regulation. ${ }^{12}$ Shavell indicates that (1) when information on preventive technology would be better with the government than with private parties and when (2) insolvency problems would arise and/or (3) for a number of reasons a liability suit would never be brought, regulation can be a more effective instrument to control externalities (like damage to $\mathrm{CI}$ ) than private law instruments like liability rules.

Turning to each of those criteria it seems that for the case of potential damage to CI resulting from technological disasters these potential weaknesses of liability rules are all of relevance. Private parties may in some cases lack adequate information on preventive technology, whereas the government could use economies of scale and thus invest in a more efficient manner in prevention. Regulation could, moreover pass on information to the parties in the market on optimal preventive technologies. The insolvency problem will obviously arise in all cases where smaller operators may cause high damage to CI of which the potential magnitude may outweigh their personal assets. Limited liability of corporations may, moreover, support the externalisation of harm to third parties and to society in general. ${ }^{13}$ To the extent that solvency guarantees would not be available or not be able to cure the under-deterrence that follows from insolvency this may equally be an argument in favour of ex ante safety regulation.

There can also be a number of reasons why tort suits are never brought (even though the conditions are in theory all met). In some cases tortfeasors can-

12 See Steven Shavell, "Liability for Harm versus Regulation of Safety", 13 Journal of Legal Studies (1984), pp. 357 et sqq.

13 For that reason the limited liability of corporate entities has been seriously criticized by Henry Hansmann and Reinier Kraakman, "Towards Unlimited Liability for Corporate Torts", 100 The Yale Law Journal (1991), pp. 1879 et sqq, especially when involuntary creditors (like tort victims) are involved.

14 For difficulties concerning access to justice see the contributions in Mark Tuil and Louis Visscher, New Trends in Financing Civil Litigation in Europe. A Legal, Empirical and Economic Analysis (Cheltenham: Edward Elgar, 2010). not be identified; there can be a long period between the accident and the damage (referred to as latency); problems of proof may arise as well as problems related to uncertainty over causation. Another weakness in liability rules is that that victims may face large hurdles e.g. to go to court and effectively litigate. Legal aid, contingency fees or other instruments to lower the barriers to access to justice are often insufficiently developed. ${ }^{14}$ Precisely given these hurdles for victims the use of liability rules may also have a rather ad hoc character as far as compensating victims of catastrophes is concerned. In other words: some may get (generous) compensation if they are successful in the "tort law lottery", whereas others may receive no compensation whatsoever. Compensation via liability rules therefore has no structural nature and may also come at odds with the equality principle.

\section{Summary}

In theory liability rules could play a role as far as preventing damage to $\mathrm{CI}$ is concerned and in providing compensation ex post. However, it seems that both goals (compensation and prevention) can only be realized with a strict liability rule. Only strict liability could lead to a full internalization of externalities and could also provide a guarantee of compensation, which the negligence rule does not. However, that guarantee can only be provided via the strict liability rule if also appropriate solutions for the insolvency problem are provided. In practice liability rules may just be an ad hoc system which is applied rarely due to the high barriers to enter the liability regime. As a result of many problems (causation, latency, proof, access to justice), liability rules may only play a very limited role or only a supplementary effect in the prevention of technological disasters which may endanger CI. The primary role will most likely be played by safety regulation as far as prevention is concerned. Liability rules can in that case at most play a supplementary role in cases where regulation fails. Also as far as ex post compensation is concerned there are probably more effective mechanisms than liability rules (such as first party insurance, risk sharing agreements etc.) that can guarantee adequate $e x$ post compensation.

Moreover, it was already mentioned that an important weakness in liability rules is that they prin- 
cipally can only play their preventive and compensating functions in cases of technological disasters where a liable tortfeasor can be identified and the damage can be directly attributed to causes that are man-made. No liable tortfeasor can be found e.g. in the case of an earthquake, a flooding or a volcanic eruption. The only possibility to apply tort law in case of natural disasters is to argue that public authorities were at fault e.g. by failing to prevent the disaster or not taking adequate measures to mitigate the damage. This hence raises the question of the adequacy of public authority liability.

\section{Public Authority Liability}

Although in theory there may be some scope to apply liability rules to public authorities (3.1), in practice there seems to be wide reluctance in legal practice to effectively apply liability rules to public authorities e.g. after a flooding or other type of natural disaster (3.2). Recent scholarship has argued that there are good reasons to treat public authorities different than other (ordinary) tortfeasors, the main reason being that an extensive public authority liability may lead to undesirable chilling effects (3.3). Those may explain the relatively limited use of liability rules as far as public authorities are concerned.

\section{Scope for Public Authority Liability: Theory}

It is well possible to theoretically imagine situations where public authorities would be at fault in case of a natural disaster causing damage to CI. In fact, some held that there are no natural disasters; there are only natural events that turn into disasters as a result of the intervention by men (Zeckhauser ${ }^{15}$ ). Indeed, there are many ways, more particularly in the design of $\mathrm{CI}$, in which it is possible to ex ante reduce the probability of damage or mitigate the seriousness of the consequences. ${ }^{16}$ Precautionary measures to reduce the likelihood of disasters causing damage to CI can be taken by individuals, but especially for large scale measures, by the government. Many disasters can be prevented and a lack of precautionary measures is often the real reason why natural events have catastrophic consequences. ${ }^{17}$ Given the scale of measures that are often needed precautionary efforts are often more efficiently undertaken by the government. The government can for example build levies to prevent flooding and structures to protect coasts from tsunamis and can introduce earthquake warning systems. More importantly, the government can issue zoning regulations, for example prohibiting constructions in flood-prone areas or prescribing particular building techniques in areas prone to earthquakes.

A failure to prevent the disaster or not taking adequate measures to mitigate the damage can hence in some cases be due to the government. It could for example be held that the government failed to give adequate warning e.g. in case of a flooding or it could be questioned why governments provide building permits allowing to construct houses in flood prone areas or on the slopes of an active volcano.

\section{Scope of Public Authority Liability: Practice}

After many natural disasters affecting CI questions are often asked concerning the role of public authorities. For example in the case of Katrina, Shughart (2006) showed that no effective precautionary measures were taken before Katrina was announced because of bureaucratic myopia, bureaucratic inertia and corruption. ${ }^{18}$ The various government reports that were published after Katrina also pointed to serious under-investments in preparedness, particularly by public authorities (both FEMA and state authorities). For example the Bipartisan committee report A Failure of Initiative reports that FEMA sustained losses of $\$ 80$ million and $\$ 90$ million in fiscal years 2003 and 2004 and that "these budget reductions were preventing FEMA officials from maintaining

15 See Richard Zeckhauser, "The Economics of Catastrophes", 12 Journal of Risk and Uncertainty (1996), pp. 113 et sqq.

16 See Herman B. Leonard and Arnold M. Howitt, "Acting in Time against Disaster: A Comprehensive Risk Management Framework", in Howard Kunreuther and Michael Useem (eds), Learning from Catastrophes. Strategies for Reaction and Response (New Jersey: Pearson Prentice Hall, 2010), pp. 18 et sqq.

17 See Phil O'Keefe, Ken Westgate and Ben Wisner, "Taking the Naturalness out of Natural Disasters", 260 Nature (1976), pp. 566 et $s q q$.

18 See William F. Shughart II, "Katrinanomics: The Politics and Economics of Disaster Relief", 127 Public Choice (2006), pp. 31 et $s q q$. 
adequate levels of trained and ready staff". ${ }^{19}$ Similar data come from the report by the Department of Homeland Security reporting inter alia that between 1995 and 2003 FEMA's budget decreased to such an extent that it was left "unable to conduct a large scale catastrophic event exercise". ${ }^{20}$

Hence, in the wake of Katrina the question of governmental responsibility was raised ${ }^{21}$ but none of those law suits succeeded. ${ }^{22}$

One reason why lawsuits against public authorities are in those cases often not brought, is that the government generously intervenes with public aid. For example in the case of Katrina a report of the US Senate refers to a total amount of $\$ 88$ billion that the US Federal Government has committed as of March 8,2006 to the response, recovery and rebuilding efforts. ${ }^{23}$

There is a serious potential of public authority liability since public choice analysis shows that politicians tend to underinvest in precautionary efforts since these do not lead to substantial political gains

19 US House of Representatives, A Failure of Initiative, Final Report of the select bipartisan committee to investigate the preparation for and response to hurricane Katrina 2006, Washington, available at www.nola.com/katrina/pdf/mainreport.pdf (last accessed on Feb. 27, 2015), 156

20 Department of Homeland Security, A Performance Review of FEMA's Disaster Management Activities in response to Hurricane Katrina, 2006, p. 129, available at: www.oig.dhs.gov/assets/MgMt/OIG_06-32_Mar06.pdf (last accessed on Feb. 26, 2015).

21 See Vicky Bier, "Hurricane Katrina as a Bureaucratic Nightmare", in Ronald J. Daniels, Donald F. Kettle and Howard Kunreuther (eds), On Risk and Disaster. Lessons from Hurricane Katrina (Philadelphia: University of Pennsylvania Press, 2006), pp. 243 et sqq.; Jonathan Walters and Ronald Kettl, "The Katrina Breakdown", in Ronald J. Daniels, Donald F. Kettle and Howard Kunreuther (eds), On Risk and Disaster. Lessons from Hurricane Katrina (Philadelphia: University of Pennsylvania Press, 2006), pp. 255 et sqq.

22 Bier, supra note 21 and Walters and Kettl, supra note 21.

23 Report of the Senate Committee on Homeland Security and Governmental Affairs, Hurricane Katrina: a nation still unprepared, executive summary, May 2006, at p. 17, available on the internet at $<$ http://www.disastersrus.org/katrina>.

24 See more particularly Ben Depoorter, "Horizontal Political Externalities: The Supply and Demand of Disaster Management", 56 Duke Law Journal (2006), pp. 101 et sqq.

25 Ronald J. Daniels and Michael J. Trebilcock, "Rationales and Instruments for Government Intervention", in Ronald J. Daniels, Donald F. Kettle and Howard Kunreuther (eds), On Risk and Disaster. Lessons from Hurricane Katrina (Philadelphia: University of Pennsylvania Press, 2006), pp. 89 et sqq., at pp. 91-92.

26 For details see Michel Cannarsa, Fabien Lafay and Oliver Moréteau, "France", in Michael Faure and Ton Hartlief (eds), Financial Compensation for Victims of Catastrophes. A Comparative Legal Approach (Vienna: Springer, 2006), pp. 81 et sqq., at pp. 94-95. during the term of office of the particular politician. ${ }^{24}$ This not only plays a role in the case of Katrina, as mentioned before, but more generally with all necessary precautionary efforts to mitigate damage that may affect CI. E.g. with respect to hurricanes it was held: "a number of important potential precautionary strategies that are designed to minimize the expected costs or consequences associated with a natural disaster (but not the risk of its occurrence which we are assuming to be exogenous) have many of the characteristics of public goods and if left purely to private markets are likely to be under-demanded and under-supplied as a result of collective action problems". 25

One of the rare cases where the question of public authority liability was raised, was in the French disastrous flooding case at Grand-Bornand which took place on 14 July 1987 and which caused 23 persons to die in addition to important damage to property. A thunderstorm in the mountains surrounding the valley caused two rivers to wash away camping grounds located nearby the river. Both the state and the local authorities were sued and held liable. ${ }^{26}$

However, in most of the cases in France, there will never be any claim on public authority liability for the reason that France has a system of mandatory insurance for natural disasters, which aims to compensate the victim.

In sum, one rarely sees cases of public authority liability in practice for the simple reason that the tendency of governments to provide ex post compensation is very strong (also because this generates high political rewards). The tendency of governments to provide this ex post compensation may to some extent even be triggered by the fear of public authority liability, thus avoiding that a particular blame would be imposed on governments.

\section{Outlook}

Summarizing, there is not a large tendency to use the possibilities of public authority liability, although theoretically the scope for public authority liability would be large. In practice, either governments intervene with ex post compensation, thus avoiding the need to call on public authority liability or in some legal systems legislators have reacted with creating immunities for public authorities in order to limit the scope of public authority liability. 
It should be added at this stage that there may indeed be reasons to treat public authorities different by ordinary tortfeasors as discussed in section 2 above. Hence, the arguments in favour of liability (providing incentives for prevention) may be different for ordinary tortfeasors than for public authorities. E.g. Schäfer and others have argued that it may be principally wrong to apply classic economic analysis of accidents to the state. ${ }^{27}$ Following public choice literature on bureaucracies they reason that states, differently than individual actors, do not maximize utility and that it may hence be wrong to apply classic economic analysis based on utility maximization to the state or to other public authorities.

Another interesting recent study by Gerrit De Geest also defends a partial immunity from tort liability for public authorities. ${ }^{28}$ De Geest explains why particularly public authorities are immune from tort liability. He argues that, differently than ordinary actors, public authorities are often so-called multi-task agents. They have to balance various external tasks that in principle could provide benefits and costs to others. However, differently than with individual actors, they do not necessarily incur these costs and benefits themselves. For those multitask agents it is important, so De Geest argues, to provide them with discretionary power to balance all external costs in an appropriate manner. This may, so he argues, be a strong argument for a more reduced liability of multitask agents (such as public authorities) than for ordinary actors.

This strongly relates to the fact that there often may be uncertainty concerning the precise tort law standard for public authorities which could easily lead to overprecaution. This overprecaution is in some cases referred to as a "chilling effect". When chilling effects (i.e. taking measures that merely aim at avoiding liability, but in fact decrease social welfare) exist, there may be arguments for a more restrictive approach to the liability of public authorities. Hence, also from this perspective, one can understand the fact that even though governments can (through their acts or omissions) undoubtedly contribute to natural disasters that may cause damage to CI, there can still be reasons to be reluctant with accepting public authority liability (as one can apparently also observe in practice). The most important theoretical foundation for such a (partial) immunity is that a public authority often acts as a multitask agent who should have some discretionary power to balance various external costs in an appropriate manner without having to fear liability, which could lead to inefficient chilling effects.

Having thus discussed that liability rules will not only play a limited role with technological disasters (2), but with natural disasters as well (given the fact that there will often be (partial) immunity of the only actors who could be held liable for public authorities, i.e. governments), this leads to the conclusion that both for technological as well as for natural disasters the scope of liability rules in providing prevention and compensation remain limited as a result of which alternative instruments will have to be called on to fulfill those roles.

\section{The Case of Nuclear Accidents}

It may be interesting to briefly analyse how international conventions have dealt with the central topic of this contribution, being the role of private liability rules in protecting CI. It hardly needs any argument that a nuclear accident could seriously endanger CI. Hence, the question arises to what extent the rules embedded in international conventions on nuclear liability correspond with the starting points for efficient liability rules as outlined above (in section 2). I will first briefly sketch the legal framework of the international nuclear liability regime (4.1); next, I will sketch the basic principles of the liability regime as incorporated into the international conventions (4.2) and finally I will provide a critical economic analysis showing that to a large extent the liability and compensation regime in the international con-

27 Hans-Bernd Schäfer, "Can Member State Liability for the Infringement of European Law Deter National Legislators?", in Thomas Eger and Hans-Bernd Schäfer (eds), Research Handbook on the Economics of European Union Law (Cheltenham: Edward Elgar, 2012), pp. 82 et sqq.; Roger Van den Bergh and Hans-Bernd Schäfer, "Liability of Member States for Infringement of the EC Treaty: Economic Arguments in Favour of a Rule of Obvious Negligence", European Law Review (1998), pp. 552 et sqq.; Roger Van den Bergh and Hans-Bernd Schäfer, "Member States Liability for Infringement of the Free Movement of Goods in the EC: An Economic Analysis", Journal of Institutional and Theoretical Economics (2000), pp. 382 et sqq. and Roger Van den Bergh, "Francovich and its Aftermath. Member State Liability for Breaches of European Law from an Economic Perspective", in Miguel Maduro and Loic Azoulai (eds), The Past and Future of EU Law. The Classics of EU Law Revisited on the 50 th Anniversary of the Rome Treaty (Oxford: Hart Publishing, 2010), pp. 423 et sqq.

28 Gerrit De Geest, "Who Should be Immune from Tort Liability?", 41 Journal of Legal Studies (2012), pp. 291 et sqq., at p. 291. 
ventions does not correspond with the economic starting points $(4 \cdot 3)$.

\section{The Legal Framework}

In the 1960s two international compensation regimes have been established for nuclear damage: the OECD regime on the one hand and the International Atomic Energy Agency (IAEA) regime on the other. Under the auspices of the Nuclear Energy Agency (NEA) of the OECD the Convention on Third Party Liability in the Field of Nuclear Energy of 29 July 1960 (Paris Convention $)^{29}$ and the Brussels Supplementary Convention to the Paris Convention on Third Party Liability in the Field of Nuclear Energy of 31 January 1963 (Brussels Supplementary Convention) ${ }^{30}$ have been developed. The IAEA developed the Vienna Convention on Civil Liability for Nuclear Damage of 21 May 1963 (Vienna Convention). ${ }^{31}$ The conventions of these two regimes together constitute what is often referred to as the first generation of nuclear liability conventions. $^{32}$

There were no significant changes to the different nuclear liability treaties until after the Chernobyl accident on 26 April $1986 .^{33}$ The accident triggered a revision process for both the NEA and IAEA regimes, resulting in the adoption of several new international conventions. Those conventions are called the second generation of nuclear liability conventions, which consist of the Joint Protocol Relating to the Application of the Vienna Convention and the Paris Convention (Joint Protocol),${ }^{34}$ the Protocol to Amend the 1963 Vienna Convention on Civil Liability for $\mathrm{Nu}-$

29 Paris Convention on Third Party Liability in the Field of Nuclear Energy, 956 UNTS 251 (Paris Convention).

30 Convention Supplementary to the Paris Convention on Third Party Liability in the Field of Nuclear Energy, 1041 UNTS 358 (Brussels Supplementary Convention).

31 Vienna Convention on Civil Liability for Nuclear Damage, 1063 UNTS 358 (Vienna Convention).

32 Michael Faure and Tom Vanden Borre, "Compensating Nuclear Damage: A Comparative Economic Analysis of the US and International Liability Schemes", 33 William \& Mary Environmental Law and Policy Review (2008), pp. 219 et sqq., at p. 219.

33 Julia A. Schwartz, "International Nuclear Third Party Liability Law: The Response to Chernobyl", in International Nuclear Law in the Post-Chernobyl Period (Paris: OECD-NEA, 2006), pp. 37 et sqq, at pp. 41-44.

34 Joint Protocol relating to the Application of the Vienna Convention and the Paris Convention, 42 Nuc. L. Bull. 56 (1988) (Joint Protocol). clear Damage (the Protocol to the Vienna Convention), ${ }^{35}$ the Convention on Supplementary Compensation for Nuclear Damage (CSC), ${ }^{36}$ the Protocol to amend the Convention on Third Party Liability in the Field of Nuclear Energy of 29 July 1960 (the Protocol to the Paris Convention) ${ }^{37}$ and the Protocol to Amend the Convention of 31 January 1963 Supplementary to the Convention of 29 July 1960 on Third Party Liability in the Field of Nuclear Energy (the Protocol to the Brussels Supplementary Convention). ${ }^{38}$

In an overview the international nuclear compensation regime, now consisting of no less than eight international conventions, can be summarized as follows in table 1.

\section{Basic Principles}

\section{a. Strict Liability}

All international conventions adopt a model of strict liability. According to the Paris Convention, the operator is liable for damage caused by a nuclear incident in a nuclear installation or involving nuclear substances coming from such installations. ${ }^{39}$ To prove the fault of nuclear operators is no longer necessary to establish liability. Liability established under the Paris Convention is quite stringent since many classical exonerations, such as force majeure, act of God or intervening acts of third persons under general tort law are no longer applicable..$^{40}$ The available exonerations are acts of armed conflict, hostilities, civil war, and insurrection. The operator is not liable for damage caused via a grave natural disaster

35 Vienna Convention as Amended by the Protocol of 12 September 1997 to Amend the Vienna Convention on Civil Liability for Nuclear Damage (the Protocol to the Vienna Convention).

36 Convention on Supplementary Compensation for Nuclear Damage (CSC).

37 Paris Convention on Third Party Liability in the Field of Nuclear Energy as amended by the Additional Protocol of 28 January 1964 and by the Protocol of 16 November 1982, and by the Protocol of 12 February 2004 (the Protocol to the Paris Convention).

38 Convention Supplementary to the Paris Convention on Third Party Liability in the Field of Nuclear Energy (as Amended by the Additional Protocol of 28 January 1964 and by the Protocol of 16 November 1982, and by the Protocol of 12 February 2004) (the Protocol to the Brussels Supplementary Convention).

39 Article III (a), the Paris Convention.

40 Point 48, the 'exposé des motifs' of the Paris Convention. 
Table 1: Overview of the international nuclear liability conventions (Faure and Vanden Borre, supra note 32, at p. 229)

\begin{tabular}{|c|c|c|}
\hline \multicolumn{3}{|c|}{ Overview of the international nuclear liability conventions } \\
\hline & First generation & Second generation \\
\hline \multirow[t]{2}{*}{ NEA-regime } & $\begin{array}{l}\text { Paris Convention on Third Party Liability in } \\
\text { the Field of Nuclear Energy of July 29, } 1960\end{array}$ & $\begin{array}{l}\text { Protocol to amend the Convention on Third Party Lia- } \\
\text { bility in the Field of Nuclear Energy of July 29, } 1960 \text { of } \\
\text { February 12, } 2004\end{array}$ \\
\hline & $\begin{array}{l}\text { Brussels Supplementary Convention to the } \\
\text { Paris Convention on Third Party Liability in } \\
\text { the Field of Nuclear Energy of January 31, } 1963\end{array}$ & $\begin{array}{l}\text { Protocol to amend the Convention of January } 31,1963 \\
\text { supplementary to the Convention of July } 29,1960 \text { on } \\
\text { Third Party Liability in the Field of Nuclear Energy of } \\
\text { February 12, } 2004\end{array}$ \\
\hline \multirow[t]{3}{*}{ IAEA-regime } & $\begin{array}{l}\text { Vienna Convention on Civil Liability for } \mathrm{Nu}^{-} \\
\text {clear Damage of May 21, } 1963\end{array}$ & $\begin{array}{l}\text { Protocol to Amend the } 1963 \text { Vienna Convention on } \\
\text { Civil Liability for Nuclear Damage of September 12, } \\
1997\end{array}$ \\
\hline & - & $\begin{array}{l}\text { Joint Protocol Relating to the Application of the Vien- } \\
\text { na Convention and the Paris Convention of Septem- } \\
\text { ber 21, } 1988\end{array}$ \\
\hline & - & $\begin{array}{l}\text { Convention on Supplementary Compensation for } \mathrm{Nu}- \\
\text { clear Damage of September 12, } 1997\end{array}$ \\
\hline
\end{tabular}

of an exceptional character unless the legislation of the Contracting Party in whose territory his nuclear installation is situated provides to the contrary. ${ }^{41}$ Similar stipulations about strict liability and exonerations can also be found under the Vienna Convention. ${ }^{42}$ However, under the Vienna Convention, there is an additional possibility for operators to be relieved of his liability: the competent court can, according to the applicable law, relieve the operator wholly or partly from his obligation if the operator can prove that damage resulted from gross negligence or an act or the omission of the victims. ${ }^{43}$

\section{b. Channelling of Liability}

Under the Paris Convention, liability is channelled to the operators. In addition to the operators, no one else is liable for the damage caused by a nuclear incident. ${ }^{44}$ The "operator" is defined as "the person designated or recognized by the competent public authority as the operator of that installation". ${ }^{45}$ On the basis of these provisions, other parties than the operator who would also engage in nuclear activities cannot be held liable, since the Paris Convention is the only legal basis for a claim against the nuclear operator in case of a nuclear accident. ${ }^{46}$ This concentration of liability is based on two reasons: to avoid the complicated legal procedures to identify the liable parties and to allow a concentration of insurance capacity. ${ }^{47}$ Under the Paris Convention, the operators in principle do not have a right of recourse against the other parties. This is because it is argued that allowing recourse will make it necessary for suppliers to seek insurance coverage and will lead to costly duplication of insurance. ${ }^{48}$ However, recourse is possible if the damage results from an act or omission

41 Article IX, the Paris Convention. This is hence similar to the formulation in the Japanese law on nuclear liability. See on the exception of the natural disaster of an exceptional character also supra section 4 .

42 Article I (1) (k), IV (1), (3), the Vienna Convention.

43 Article IV (2), the Vienna Convention.

44 Article VI (a), (b), the Paris Convention.

45 Article I (a) (vi), the Paris Convention.

46 Article VI (c)(ii), the Paris Convention.

47 Point 15, the 'exposé des motifs' of the Paris Convention.

48 Point 18, the 'exposé des motifs' of the Paris Convention. 
done with the intent to cause damage or if and to the extent provided by contract. ${ }^{49}$ The Vienna Convention also has similar provisions. ${ }^{50}$

\section{c. Financial Limit}

Obviously, the first party to be held liable under the international conventions is the operator of the plant where the nuclear incident occurred. However, this liability of the nuclear operator is capped. The Paris Convention sets the maximum liability of the operator at 15 million Special Driving Rights (SDRs) (17.03 million Euro), but allows the Contracting Party to establish by legislation a greater or lesser amount considering the capacity of insurance and financial security. The Contracting Party can also require a lower amount according to the nature of the installation. The lower amount should be no less than 5 million SDRs (5.68 million Euro)..$^{51}$ The Paris Convention introduces a cap on liability, taking into account the difficulties of operators to seek financial security. ${ }^{52}$ This allows the Contracting Parties to set the limit higher than that set in the Paris Convention. For example, in Sweden, the limit on liability is set at 300 million SDRs (340.55 million Euro) according to the Nuclear Liability Act (SFS 1968:45). ${ }^{53}$ Germany even adopted a system with unlimited liability. ${ }^{54}$ Under the Vienna Convention, the cap of liability should be no less than 5 million US dollars (5.68 million Euro) ${ }^{55}$

49 Article VI (f), the Paris Convention.

50 Article II (5), X, the Vienna Convention.

51 Article VII (b), the Paris Convention.

52 Point 43, the 'exposé des motifs' of the Paris Convention.

53 OECD: Nuclear Legislation in OECD Countries, Regulatory and Institutional Framework for Nuclear Activities: Sweden, p. 13, available on the internet at <http://www.oecd-nea.org/law/ legislation/sweden.pdf $>$.

54 Gesetz über die friedliche Verwendung der Kernenergie und den Schutz gegen ihre Gefahren (Atomgesetz - AtG) vom 23. Dezember 1959, Neufassung vom 15. Juli 1985, letzte Änderung vom 31. Juli 2011, (Act on the peaceful utilisation of nuclear energy an the protection against its hazards (Atomic Energy Act) of 23 December 1959, as amended and promulgated on 15 July 1985 , last amendment of 31 July 2011), §31.

55 Article V, the Vienna Convention.

56 Article VII (a) (b), the Protocol to the Paris Convention.

57 Article X (b), the Protocol to the Paris Convention.

58 Article V (1), the Protocol to the Vienna Convention.

59 Article X, the Paris Convention; Article VII, the Vienna Convention.

60 Article XI, the Paris Convention; Article VIII, the Vienna Convention.
It is, however, important that in the second generation of nuclear liability conventions a few important changes have been made. These refer inter alia to an increase in the amount of the limitation of liability. The Protocol to the Paris Convention increases the limit for nuclear operators to be no less than 700 million Euro. The Contracting party can reduce the liability to be no less than 70 million Euro for an incident originating from a nuclear installation, or to be no less than 80 million Euro for the carriage of nuclear substances according to the reduced risks. ${ }^{56}$ The Convention even allows the adoption of unlimited liability by the Contracting Parties, as long as the financial security required is no less than the amount mentioned above. ${ }^{57}$ The compensation capacity also increased under the IAEA regime. The Protocol to the Vienna Convention increases the liability limitation to no less than 300 million SDRs(340.55 million Euro), or no less than 150 million SDRs (170.27 million Euro), provided that the Installation State will make public funds available to cover the amount between the set limitation to 300 million SDRs (340.55 million Euro). ${ }^{58}$

\section{d. Compulsory Insurance}

To seek financial security coverage for the operator's liability is important for international regimes of nuclear liability. Both conventions require the operator to have and maintain insurance or other financial security up to the cap of its liability. ${ }^{59}$ Insurance is the most popularly used instrument for an operator to cover its liability. In fact, the cap on liability is usually set as the maximum available amount from the insurance market. It is for the Contracting Parties to decide the nature, form and extent of the compensation according to applicable national law. ${ }^{60}$

\section{e. Public Funding}

The liability limits established under the Paris Convention and the Vienna Convention are quite low compared to the potential catastrophic damage that a nuclear incident can cause. The liability is limited to promote the development of the peaceful use of nuclear energy. To provide the potential victims better protection, the Brussels Complementary Convention was established under the auspices of the NEA in 1963. Under the Brussels Complementary Convention, two additional layers of compensation are added 
in terms of public funds. Therefore, the total amount of money available for compensation is increased to 300 million SDRs (340.55 million Euro), and a third layer compensation system is established: firstly, the operator is liable up to an amount of at least 5 million SDRs (5.68 million Euro) via its financial security; between this amount and 175 million SDR (198.65 million Euro), the Installation State needs to make public funds available; for the amount between 175 and 300 million SDRs (198.65 and 340.55 million Euro), compensation is made out of public funds by all Contracting Parties according to a specific formula. ${ }^{61}$ The Installation State can escape its obligation under the second layer by setting the liability limit at no less than 175 million SDRs (198.65 million Euro). In that case the whole amount up to 175 million SDRs (198.65 million Euro) needs to be made available by liable operators. Therefore, a three-tier compensation system was established.

Moreover, the amounts of public funding in the second and third tier of compensation have also been changed in the second generation of nuclear liability conventions. From the maximum amount of operators' liability set by the Protocol to the Paris Convention up to 1200 million Euro, the Installation State needs to pay in terms of public funds. Public funds need to be made available by all Contracting Parties according to a set formula of compensation between the amounts of 1200 million Euro and 1500 million Euro. ${ }^{62}$ Thus the available resources for compensation in case of a nuclear accident are increased significantly: from 300 million SDRs (340.55 million Euro) to 1,500 million Euro.

As we just mentioned, the protocol to the Vienna Convention also introduced a second layer of compensation by forcing the Installation State to make public funds available to cover the amount between the limitation and 300 million SDRs (340.55 million Euro). However, although the amount has been significantly increased, it is modest compared to the possible significant damage and it is set at the same level as the original Paris Convention and the Brussels Supplementary Convention. The CSC Convention also provides two tiers of compensation: a first 300 million SDRs (340.55 million Euro) is paid by public funds from the Installation State and another 300 million SDRs (340.55 million Euro) from the collective funds from the Contracting Parties. ${ }^{63}$

These new conventions and protocols are designed to overcome the deficiency of the first gener- ation of nuclear liability conventions. However, the revisions have created eight international conventions on nuclear liability, which lead to the so-called "labyrinth of international conventions" dealing with nuclear liability issues. ${ }^{64}$ Moreover, among the five new conventions, only two have come into force: the Joint Protocol entered into force in 1992 and the Protocol to the Vienna Convention came into force in 2003. Until now (March 2015), only five countries have ratified the Protocol to the Vienna Convention: Argentina, Belarus, Latvia, Morocco and Romania, and none of them have a significant nuclear generating capacity. ${ }^{65}$ There are still many large nuclear power generating countries which are not a member of any of those conventions, such as the US, Canada, Japan, China, South Korea, Russia, South Africa and Switzerland.

\section{Critical Economic Analysis}

In fact, critical comments could be formulated on each of the specific aspects of the international nuclear liability regime. The strict liability as such is, of course, in line with the economic analysis provided in section 2. Strict liability, so it is often held in the literature, ${ }^{66}$ will lead to optimal incentives for care and activity levels of nuclear operators. By exposing a power plant operator to strict liability, a full internalization of the externality caused by the nuclear accident can be generated. The fact that the second generation international conventions also exclude "a grave natural disaster of an exceptional nature" as a defence can only be welcomed from an economic per-

61 Article III (a)(b), the Brussels Complementary Convention.

62 Article III (b), the Protocol to the Brussels Complementary Convention.

63 Article III 1, IV 1, the CSC Convention.

64 For the patchy and complicated approach under international nuclear liability conventions, see Duncan E.J. Currie, "The Problems and Gaps in the Nuclear Liability Conventions and an Analysis of How an Actual Claim Would Be Brought under the Current Existing Treaty Regime in the Event of a Nuclear Accident", 35 Denver Journal of International Law and Policy (2006), pp. 85 et sqq., at p. 85 .

65 Of these five countries, only Argentina and Romania have nuclear capacity. The net nuclear power generating capacity of Argentia is 935 MWe and that of Romania is 1300 MWe in 2009. See Julia A. Schwartz, "Great Expectations: Where Do We Stand with the International Nuclear Liability Conventions?", in Norbert Pelzer (ed.), European Nuclear Liability Law in a Process of Change (Berlin: Nomos, 2009), pp. 43 et sqq., at p. 50.

66 See e.g. Shavell, supra note 7 . 
spective. This change is desirable since it will provide incentives to operators to construct nuclear installation more carefully to make them more disaster resistant.

An aspect which has already received much criticism is the exclusive channelling of the civil liability to the operator of the nuclear power plant. ${ }^{67}$ The problematic aspect of channelling is that it excludes the liability of others who could have contributed to the risk as well. ${ }^{68}$ In theory, operators could negotiate with other parties and make agreements to abolish the channelling. However, a recent survey shows that the differences in bargaining power between the operators and e.g. the designers or constructors make it in fact impossible for them to impose liability on others. ${ }^{69}$ The case of the recent Fukushima incident shows the potentially catastrophic effects of an exclusive channelling to the operator of the nuclear power plant. It is reported that the meltdown of the nuclear reactors may have been caused by the simple fact that the generators for the cooling system were located in the basement of the turbine buildings, which of course made them very vulnerable to a tsunami. ${ }^{70}$ The question could be asked whether this is the result of negligent action by the operator TEPCO, or rather the result of bad design or engineering by General Electric. In the latter case a channelling of the liability to the operator TEPCO would

67 Michael Faure and Karine Fiore, "The Civil Liability of European Nuclear Operators: Which Coverage for the New 2004 Protocols? Evidence from France", 8 International Environmental Agreements (2008), pp. 228 et sqq., at pp. 229-230.

68 Michael Trebilcock and Ralph A. Winter, "The Economics of Nuclear Accident Law", 17 International Review of Law and Economics (1997), pp. 215 et sqq., at p. 215.

69 Evelyne Ameye, "Channelling of Nuclear Third Party Liability towards the Operator: Is it Sustainable in A Developing Nuclear World or is there a Need for Liability of Nuclear Architects and Engineers?", 19 European Energy and Environmental Law Review (2010), pp. 33 et sqq., at p. 56.

70 See Reiji Yoshida, GE Plan Followed with Inflexibility, The Japan Times (14 July 2011), available at the internet at <http://www .japantimes.co.jp/text/nn20110714a2.html>.

71 Hans-Bernd Schäfer and Frank Müller-Langer, "Strict Liability versus Negligence", in Michael Faure (ed.), Tort Law and Econom ics (Cheltenham: Edward Elgar, 2009), pp. 3 et sqq.

72 For example, unlimited liability was adopted in Austria and Germany. In Denmark and Sweden, the unlimited liability is seriously considered or will be applicable when the revised Paris Convention comes into force. See Schwartz, supra note 65 , at p. 43,54 .

73 Cited in Currie, supra note 64, at p. 92.

74 Michael Faure and Karine Fiore, "An Economic Analysis of the Nuclear Liability Subsidy", 26 Pace Environmental Law Review (2009), pp. 419 et sqq., at p. 419. be particularly problematic since channelling would lead to an exclusion of liability of all other parties who contributed to the risk, in this particular case (at least potentially) General Electric. Channelling may thus negatively affect incentives of other parties involved in the risk

Economic analysis also makes clear that for strict liability to work efficiently the amount of compensation should be equal to the actual costs of the accident. ${ }^{71}$ Under the international nuclear conventions, the liability is capped. This not only leads to undercompensation of victims; liable parties will also have reduced incentives to prevent the damage to the extent of the cap. Though the financial cap under the international conventions has been increased through the years and they allow the member states to adopt unlimited liability, only a limited number of countries adopted unlimited liability in practice. $^{72}$ The amounts set under the protocols are still nowhere near to the real possible costs of a major nuclear accident. Though there is no consensus on the estimation of the costs of the worst nuclear accidents yet, the Chernobyl accident and Fukushima accident have caused damage much higher than the limit set in nuclear conventions. Some studies also estimate the possible damage to be as high as several billions of Euros: it is estimated that the total damage of a reactor meltdown in Germany would be over 5,000 billion Euro; a Greenpeace review of the costs cited some estimations, varying from several billion to 6.8 trillion US dollars. ${ }^{73}$ Given the potential catastrophic losses the nuclear accidents can create, the limited liability creates a substantial subsidy to the nuclear industry. This subsidy may not only lead to a less than efficient care level adopted by operators, it also favours nuclear energy compared to other kinds of energy. This may lead to a too high demand for nuclear energy as well. For example, a research showed that with subsidy to the nuclear sector, the energy production costs for nuclear energy is lower than coal, gas and renewable energy sources. ${ }^{74}$

Finally, we can take a look at the third aspect of the international conventions that has received substantial criticism, being public funding. Under the Paris Convention, a three tiered compensation system has been established. The state where the nuclear installation is installed needs to make public funds available to cover the second tier of damage and the contracting parties together should provide a collective fund to provide the third tier of compen- 
sation. The public funds intervention is even strengthened under the second generation of conventions. There was a shift towards public funding in those conventions. ${ }^{75}$ The required amount of public funds from Installation States under the Paris Convention has increased substantially in the second generation of conventions. The shift towards public funding has been criticized by law and economics literature, since it constitutes a subsidy to operators and thus further dilutes the incentives for operators to take efficient care. ${ }^{76}$

\section{Concluding Remarks}

The goal of this contribution was to analyse the role of private liability in protecting CI. In that respect I started with the classic distinction between natural disasters (where in principle no liable tortfeasor can be identified) and technological disasters. Obviously, as held in section 2 , the scope for using liability rules is larger with technological than with natural disasters. However, even with technological disasters, a lot of specific conditions would have to be met for a liability regime to function optimally in protecting CI. Liability would have to be strict, there should be no channelling of liability, as a result of which all those who contributed to the risk should be exposed to liability. Moreover, liability should be unlimited and of course operators should hence be exposed to the full cost of the damage they are creating.

The brief discussion of nuclear liability conventions in section 4 showed that the important case of nuclear accidents (which obviously can be a main source of disruption of CI) does not at all correspond with those economic starting points. Liability is strict, but it is exclusively channelled to the liable operator, liability is, moreover, limited to quite low amounts and in fact compensation is mostly provided via public funding, thus providing a subsidy to nuclear power and reducing the operator's incentives to reduce the risk by investing in preventive technology. The reason why the nuclear liability conventions were conceived in this manner in the 1960s, when they were created, may be obvious: their goal was to protect the interest of the nuclear industry and also of the suppliers of nuclear material who were based in the US. The exclusive channelling of liability to operators (in Europe) hence avoided liability claims against American suppliers of nuclear material.
Nowadays, as the case of Fukushima shows (which largely follows the same principles as in the international conventions, even though Japan has its own regime), this liability framework is quite problematic since it violates basic economic principles by providing insufficient incentives for prevention. However, given the strong political power of the energy sector in most countries it is clear that changing this regime, notwithstanding large criticism from academia and civil society, is not an easy goal to achieve. That may hence seriously limit the role of private liability in protecting CI, not only in this domain, but also in many other areas where technological disasters are at stake and the government provided (via limitations on liability) protection to the industry is involved.

Another issue is that ordinary private operators may often not be liable for natural disasters (unless the natural disaster triggers a technological disaster, like in the case of Fukushima). The only possible tortfeasor that comes into the picture in case of a natural disaster is often a public authority having contributed to the damage, for example by allowing building on slopes of volcanoes or in flood prone areas or by taking insufficient measures to protect CI. However, in practice the number of cases where liability of public authorities for those types of natural disasters is accepted is relatively small. There are, as we argued in section 3, also good arguments to be relatively restrictive as far as public authority liability is concerned, public authorities often being multitask agents that have to balance different externalities against each other and thus may need a large discretionary power in their decision-making.

There may, moreover, be other reasons why the liability regime is often not able to provide its preventive and compensatory functions in case of disasters that threaten CI. In some cases information on optimal preventive technology is better available from the government than from private operators; moreover, in some cases the damage may be so high that it largely outweighs the individual assets of operators as a result of which an insolvency problem will

75 Tom Vanden Borre, "Shifts in Governance in Compensation for Environmental Damage: 20 Years after Chernobyl", in Michael Faure and Albert Verheij (eds), Shifts in Compensation for Environmental Damage (Vienna: Springer, 2007), pp. 261 et sqq., at p. $261,305$.

76 See Faure and Vanden Borre, supra note 32, at p. 219 
occur. Moreover, the deterrent effect of law suits may fail for a variety of reasons (limited access to justice, causation problems and issues of proof). For those reasons the role of liability rules in providing incentives to prevent damage to CI may often be limited. The same may be true for the compensatory role of liability rules, which was, however, not the main focus of this contribution. There again, other mechanisms such as for example first party insurance, eventually complemented with a government provided guarantee (in order to increase supply on the insurance market) may better be able to provide compensation, also in case of damage to CI.
A final point which was not addressed in this contribution, but which may obviously have a bearing on both the preventive as well as the compensatory effects of liability rules relates to the fact that the government may in some cases be the primary victim and tortfeasor as well. CI may often be in the possession of the government and therefore the primary task to restore that infrastructure may rest on the government, irrespective of any liability regime. That obviously raises important issues as well with respect to the use of liability rules. Those were, however, beyond the scope of this contribution and may be interesting for further research. 